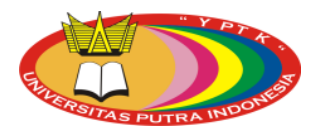

Surnal Pendidikan Oeknologi Informasi

http://1ppm.upiyptk.ac.id/ojsupi/index.php/pti

Vol. 6 Issue 2, Oktober 2019, Hal 14-24

ISSN: 2355-9977 | E-ISSN : 2685-3914

\title{
Perancangan dan Pembuatan Media Pembelajaran Mobile Learning Berbasis Android Untuk Mata Pelajaran Produktif Perakitan Personal Komputer (PC) (Studi Kasus Kelas XI Jurusan Teknik Komputer Jaringan SMK Muhammadiyah 1 Padang)
}

\author{
Astri Indah Juwita \\ Universitas Putra Indonesia YPTK Padang \\ Email:astriindahjuwita@gmail.com
}

\begin{abstract}
Abstrak
Penelitian dan pengembangan ini bertujuan untuk menghasilkan produk berupa Mobile Learning berbasis Android untuk siswa kelas X jurusan teknik komputer dan jaringan di SMK Muhammadiyah 1 Padang. Metode penelitian yang digunakan adalah metode penelitian pengembangan (Research and development), dengan desain pengembangan yang dipilih adalah menggunakan model pengembangan 4D. Langkah-langkah pengmbangannya adalah sebagai berikut : (1) define, (2) design, (3) development, (4) disseminate. Validasi produk pengembangan mencakup (1) uji ahli isi mata pelajaran, (2) uji ahli media pembelajaran, (3) uji ahli desain pembelajaran, (4) uji coba perorangan, (5) uji coba kelompok kecil, (6) uji coba kelompok besar, (7) uji coba kepada guru mata pelajaran.

Hasil penilaian para ahli ditinjau dari aspek Kelayakan Isi : 88,00\%, Komponen kebahasaan : 86,67\%, Komponen penyajian : 87,78\%, Komponen Kegrafikan : 91,87\%. Secara keseluruhan penilaian uji Validator terhadap mobile learning Perakitan PC sebesar 88,58\%, sehingga tingkat validitas dapat di interprestasikan valid digunakan. Hasil penilaian uji kepraktisan di tinjau dari aspek kemudahan dalam penggunaan : 72,87\%, efektifitas waktu pembelajaran: $87,67 \%$, manfaat : $92,40 \%$, secara keseluruhan penilaian kepraktisan terhadap mobile learning sebesar $84,29 \%$, sehingga tingkat praktikalitasnya dapat di interprestasikan praktis digunakan. Hasil penilaian uji keefektifan ditinjau dari aspek senang belajar : 91,80\%, adanya bahan ajar yang menarik dalam belajar : 83,23\%, secara keseluruhan penilaian keefektifan terhadap mobile learning sebesar 87,51\%, sehingga tingkat efektifitasnya dapat di interprestasikan sangat efektif digunakan. Berdasarkan penilaian beserta masukan ahli serta hasil dari uji coba lapangan media pembelajaran mobile learning berbasis android sudah teruji kelayakan, keunggulan dan dapat digunakan pada proses pembelajaran pada mata pelajaran Perakitan PC Jurusan TKJ di SMK Muhammadiyah 1 Padang.
\end{abstract}

Kata kunci : Perancangan ,Mobile Learning, Interaktif.

\section{PENDAhuluan}

Kemajuan teknologi modern merupakan faktor utama dalam menunjang usaha pembaharuan. Peranan teknologi sangat penting terutama pada masyarakat negara-negara berkembang. Pemerintah dan masyarakat memberikan perhatian secara maksimal terhadap perkembangan teknologi saat ini, karena mereka menyadari peranan dan fungsi teknologi itu sangatlah penting bagi kehidupan mereka.

Dengan adanya teknologi dalam bidang komunikasi telah mempengaruhi seluruh sektor termasuk pendidikan. Sistem pendidikan saat ini telah mengalami kemajuan yang sangat pesat. Berbagai cara telah dikenalkan serta digunakan dalam proses belajar mengajar dengan harapan pengajaran guru akan lebih berkesan dan pembelajaran bagi murid akan lebih bermakna. Pemanfaatan teknologi komunikasi saat ini juga banyak di manfaatkan untuk kegiatan pendidikan, teknologi pendidikan, serta media pendidikan dalam rangka belajar mengajar.

Tingkat pemahaman siswa yang berbeda menuntut guru atau pendidik lebih kreatif dalam menyampaikan materi. Dengan adanya media pembelajaran dapat membantu guru disekolah untuk kepentingan pembelajaran. Melalui media pembelajaran diharapkan guru lebih kreatif dan inovatif dalam memberikan pembelajaran kepada siswa. Media pembelajaran digunakan sebagai sarana belajar mengajar baik di sekolah maupun dimana saja yang bertujuan untuk dapat meningkatkan mutu pendidikan. 
Media dalam pembelajaran dapat di artikan sebagai segala sesuatu yang dapat dipergunakan untuk merangsang pikiran, perasaan, perhatian dan kemampuan atau ketrampilan pembelajar sehingga dapat mendorong terjadinya proses belajar.

Penggunaan media pembelajaran di sekolah sangat membantu menarik perhatian siswa, penggunaan media yang menarik dan tidak biasa dapat merangsang dan menarik perhatian siswa untuk fokus pada materi yang di sampaikan melalui media tersebut. Berdasarkan Pengamatan yang peneliti lakukan di Sekolah Menengah Kejuruan Muhammadiyah 1 Padang, ada beberapa media pembelajaran yang digunakan, baik itu berupa modul-modul, penggunaan infokus dan lainnya, namun masih belum efektif dalam menarik antusiasme siswa untuk memperhatikan dan mengambil informasi dari media yang di gunakan tersebut sehingga belum menunjang proses pembelajaran. Guru mata pelajaran Perakitan PC di SMK Muhammadiyah 1 Padang juga mengeluhkan kurangnya minat belajar siswa karena belum memiliki media belajar yang mampu meningkatkan minat belajar siswa kelas X TKJ SMK Muhammadiyah 1 Padang.

\section{Tinjauan Literatur}

\subsection{Media Pembelajaran}

Guru mempunyai peranan dalam proses belajar mengajar (PBM), untuk membelajarkan siswa agar tujuan pendidikan tercapai, yaitu membentuk manusia yang cerdas, terampil dan berbudi pekerti luhur. Seorang guru, selain menggunakan metode yang tepat dan variatif dalam menyampaikan materi, juga membutuhkan suatu media pendukung yang dapat meningkatkan motivasi siswa dalam belajar. Namun dengan masih terbatasnya media yang digunakan belum memperoleh hasil belajar yang diinginkan. Dengan masih banyaknya siswa yang mendapatkan nilai rendah. Khususnya pada mata pelajaran Perakitan PC, yang mana mata pelajaran ini sulit dimengerti oleh siswa jika hanya menggunakan media modul dan buku panduan siswa.

Salah satu yang menarik untuk dijadikan media pembelajaran adalah penggunaan teknologi multimedia, yaitu teknologi yang yang menggabungkan media gambar, video, audio dan animasi yang di muat dalam sebuah Mobile/handphone yang di kombinasikan dengan materi pelajaran.

Oleh sebab itu dengan adanya teknologi multimedia dan informasi diharapkan dapat membuat suatu media yang menarik baik itu dari teori maupun praktek, dengan demikian diharapkan siswa lebih mengerti dan tidak susah lagi dalam pelajaran khusunya pada mata pelajaran perakitan PC di SMK Muhammadiyah 1 Padang.

\subsection{Mobile Learning}

Pada Mobile Learning berbasis Android ini mempunyai animasi yang menarik dan sesuai dengan tujuan pembelajaran, sehingga dapat memotivasi siswa dalam proses belajar mengajar. Selain itu, media Mobile Learning berbasis Android ini juga dilengkapi dengan alat evaluasi berupa test untuk mengukur ketuntasan belajar siswa yang disesuaikan dengan kurikulum pembelajaran. Jadi, penggunaan media pembelajaran dengan menggunakan Mobile Learning berbasis Android ini diharapkan hasil belajar siswa akan lebih baik.

\section{Metode Penelitian}

\subsection{Jenis Penelitian}

Perancangan dan pembuatan Mobile Learning ini dilakukan pada mata diklat Peraitan PC merupakan penelitian dan pengembangan (research and development). Menurut sugiyono (2011: 297) metode penelitian dan pengembangan adalah metode penelitian yang digunakan untuk menghasilkan produk tertentu dan mengkaji keefektifan produk tersebut.

\subsection{Tempat dan waktu Penelitian}

Tempat penelitian dengan judul " Perancangan dan Pembuatan mobile learning berbasis android Mata Pelajaran perakitan pc di Kelas X TKJ SMK Muhammadiyah 1 Padang Tahun Pelajaran 2016/2017 dilakukan di SMK Muhammadiyah 1 Padang terletak di Jln. By. Pass KM 6 Lubuak Begalung, Padang, Sumbar, Telp. (0751-777663.Waktu penelitian berlangsung di semester Genap pada tahun ajaran 2016/2017. 


\subsection{Prosedur pengembangan}

Prosedur pengembangan media pembelajaran interaktif dengan menggunakan Model pengembangan perangkat. Menurut Thiagarajan, dkk (1974) adalah model 4-D, yang terdiri dari 4 tahap pengembangan, yaitu define, design, develop dan dessimenate. Model pengembangan Four-D (4-D).

\subsection{Rancangam Pegembangan}

Perancangan Interface mobile learning berbasis android Mata Pelajaran perakitan pc adalah sebagai berikut:

1. Rancangan Antar Muka (Interface) Tampilan input dan output Mobile Learning

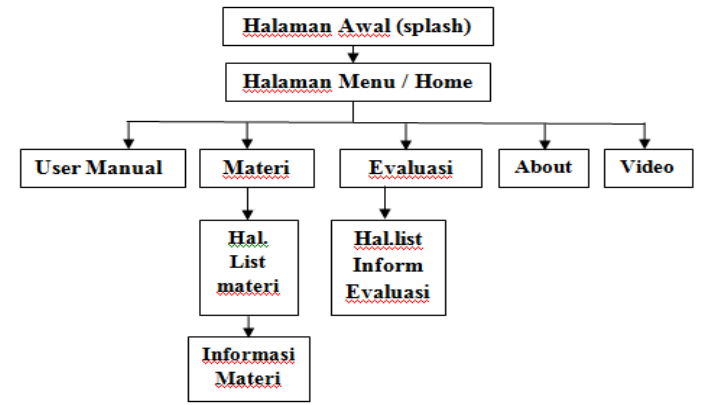

Gambar 1. Rancangan Tampilan input dan output

2. Rancangan Form Menu

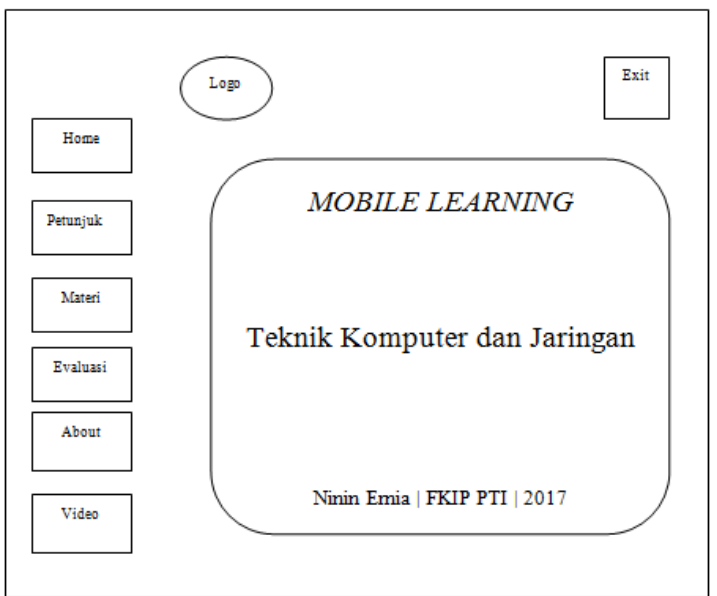

Gambar 2. Rancangan Menu Home mobile learning berbasis android

\subsection{Instrumen Pengumpulan Data}

1. Instrumen validitas

Instrumen kevalidan digunakan untuk mengetahui apakah Mobile Learning berbasis android yang telah dirancang valid atau tidak. Dengan kata lain, seluruh instrument yang telah dirancang akan divalidasi instrument tersebut. Lembar validasi pada penelitian ini adalah validasi yang dilakukan oleh validator.

Tabel 1. Kisi-Kisi Angket Validator

\begin{tabular}{llll}
\hline No & \multicolumn{1}{c}{ Indikator } & No Item & $\begin{array}{c}\text { Jumla } \\
\text { h }\end{array}$ \\
\hline 1 & Kelayakan Isi. & $1,2,3,4,5$ & 5 \\
2 & Komponen & $6,7,8,9$ & 4 \\
& Kebahasan. & & \\
3 & Komponen & $10,11,12,1$ & 6 \\
& Penyajian. & $3,14,15$ & \\
4 & Komponen & $16,17,18,1$ & 5 \\
& Kegrafikan. & 9,20 &
\end{tabular}


Instrumen yang digunakan disusun menurut pola skala dalam bentuk kontiniu yang terdiri dari lima kategori dan pernyataan angket bersifat positif. Untuk mengubah data kualitatif ke bentuk kuantitatif, maka angket selain di beri alternatif jawaban masing-masing mempunyai bobot dan skor dari setiap jawaban dari pernyataan dapat dilihat pada tabel berikut :

Tabel 2. Penilaian Jawaban

\begin{tabular}{cccc}
\hline Pilihan & $\begin{array}{c}\text { Keteranga } \\
\text { n }\end{array}$ & $\begin{array}{c}\text { Bositi } \\
\text { f }\end{array}$ & Negatif \\
\hline Sangat Setuju & SS & 5 & 1 \\
Setuju & S & 4 & 2 \\
Kurang Setuju & KS & 3 & 3 \\
Tidak Setuju & TS & 2 & 4 \\
Sangat Tidak & STS & 1 & 5 \\
Setuju & & & \\
\hline
\end{tabular}

Sumber: Sugiyono (2014 : 93)

2. Instrumen Praktikalitas

Setelah instrument dinyatakan valid oleh validator, selanjutnya beberapa instrument tersebut digunakan untuk uji kepraktisan. Adapun instrument yang digunakan pada uji coba kepraktisan berupa angket kepraktisan.

Angket sangat dibutuhkan untuk mengumpulkan data-data atau informasi yang dibutuhkan oleh penulis sebagai bahan penelitian yang bertujuan untuk mengetahui kelayakan dan menarik atau tidaknya Mobile Learning berbasis android yang dibuat oleh penulis sebagai alternatif pembelajaraan. Berikut adalah kisi-kisi dari angket praktikalitas :

Tabel 3. Kisi-Kisi Angket Praktikalitas

\begin{tabular}{clcc}
\hline No & \multicolumn{1}{c}{ Indikator } & No Item & $\begin{array}{c}\text { Jumla } \\
\text { h }\end{array}$ \\
\hline 1 & Kegunaan & 8 \\
& Penggunaan. & $1,2,3,4,5,6,7,8$ & \\
2 & EfektifitasWaktu & $9,10,11,12,1$ & 5 \\
& $\begin{array}{l}\text { Pembelajaran. } \\
3\end{array}$ & 3 & \\
& Manfaat. & $14,15,16,17$, & 5 \\
\multicolumn{2}{c}{ Total Item } & $\mathbf{1 8}$ \\
\hline
\end{tabular}

Tabel 4. Penilaian Jawaban

\begin{tabular}{lcc}
\hline Option & Keterangan & Bobot \\
\hline Sangat Baik & SS & 5 \\
Setuju & S & 4 \\
Ragu-Ragu & R & 3 \\
Kurang Baik & TS & 2 \\
Tidak Baik & STS & 1 \\
\hline
\end{tabular}

Sumber: Sugiyono (2014 : 93)

\section{Instrumen Efektivitas}

Cara pengujian keefektifan Mobile Learning berbasis android digunakan angket motivasi belajar. Untuk mengetahui motivasi belajar siswa, siswa mengisi angket motivasi belajar. Angket motivasi belajar diberikan setelah siswa mengikuti proses pembelajaran dengan Mobile Learning berbasis android. Tujuan pemberian angket motivasi belajar ini adalah untuk mendapatkan gambaran bagaimana tingkat motivasi 
belajar siswa setelah mengikuti proses pembelajaran yang dilaksanakan dengan menggunakan Mobile Learning berbasis android. Berikut adalah kisi-kisi dari angket efektifitas :

Tabel 5. Kisi-Kisi Angket Efektivitas

\begin{tabular}{clcc}
\hline No & \multicolumn{1}{c}{ Indikator } & No Item & $\begin{array}{c}\text { Jumla } \\
\text { h }\end{array}$ \\
\hline 1 & Senang Belajar. & $1,2,3,4,5,6,7$ & 7 \\
2 & Adanya Bahan & $8,9,10,11$ & 4 \\
& Ajar Yang & & \\
& Menarik Dalam & & \\
& Belajar. & & $\mathbf{1 1}$ \\
\hline \multicolumn{2}{c}{ Total Item } & & \\
\hline
\end{tabular}

Instrumen yang digunakan disusun menurut pola skala dalam bentuk kontiniu yang terdiri dari lima kategori dan pernyataan angket bersifat positif dan negatif. Untuk mengubah data kualitatif ke bentuk kuantitatif, maka angket selain di beri alternatif jawaban masing-masing mempunyai bobot dan skor dari setiap jawaban dari pernyataan dapat dilihat pada tabel berikut :

Tabel 6. Penilaian Jawaban

\begin{tabular}{lccc}
\hline Option & Keterangan & \multicolumn{2}{c}{ Bobot } \\
& & Positif & Negatif \\
\hline $\begin{array}{c}\text { Sangat } \\
\text { Baik }\end{array}$ & SS & 5 & 1 \\
$\quad$ Setuju & S & 4 & 2 \\
$\quad$ Ragu- & R & 3 & 3 \\
Ragu & & & \\
Tidak Setuju & TS & 2 & 4 \\
Sangat Tidak & STS & 1 & 5 \\
Setuju & & & \\
\hline
\end{tabular}

Sumber: Sugiyono (2014 : 93)

\subsection{Teknik Analisa Data}

Analisis data penelitian ini dilakukan dengan menggunakan analisis deskriptif. Analisis meliputi analisis validitas, analisis praktikalitas dan analisis efektifitas Mobile Learning berbasis android.

1. Analisis Uji Validitas Mobile Learning

Analisis uji validitas Mobile Learning berbasis android berupa komponen kelayakan isi, kebahasan dan penyajiannya berdasarkan lembar uji validitas yang dilakukan dengan langkah sebagai berikut :

a. Memberikan skor jawaban dengan kriteria berdasarkan skala Likert yang dimodifikasi oleh Sugiyono (2014: 93) yaitu :

Tabel 7. Penilaian Jawaban

\begin{tabular}{lccc}
\hline \multicolumn{1}{c}{ Pilihan } & $\begin{array}{c}\text { Ketera } \\
\text { ngan }\end{array}$ & Positif & Negatif \\
\hline $\begin{array}{l}\text { Sangat } \\
\text { Setuju }\end{array}$ & SS & 5 & 1 \\
Setuju & S & 4 & 2 \\
Kurang & KS & 3 & 3 \\
Setuju & & & \\
Tidak Setuju & TS & 2 & 4 \\
Sangat & STS & 1 & 5 \\
Tidak Setuju & & & \\
\hline
\end{tabular}

Sumber: Sugiyono (2014 : 93)

b. Menentukan skor tertinggi, Skor tertinggi $=$ jumlah validator $\mathrm{x}$ jumlah item pertanyaan $\mathrm{x}$ skor maksimum.

c. Menentukan jumlah skor dari masing-masing validator dengan menjumlahkan semua skor yang di peroleh dari masing-masing indikator. 
d. Menentukan skor yang diperoleh dengan menjumlahkan skor dari masing-masing validator.

e. Penentuan nilai validitas dimodifikasi dari Purwanto (2010:102) sebagai berikut :

$N P=R / S M \times 100$ (1)Keterangan :

$\mathrm{NP}=$ Nilai persen yang dicari atau yang diharapkan

$\mathrm{R}=$ Skor mentah yang diperoleh Validator

$\mathrm{SM}=$ Skor Maksimum ideal dari tes yang bersangkutan

$100=$ Bilangan Tetap

f. Untuk mencari Distribusi Frekuensi dari Validitas dimodifikasi dari Agus Irianto sebagai berikut :

1) Menghitung jarak atau rentang $(R) R=$ data tertinggi - data terendah

2) Mencari jumlah Jumlah kelas (K) $K=1+3.3 \log n$

3) Menghitung panjang kelas interval (P) $\mathrm{P}=\mathrm{R} / \mathrm{K}$

g. Memberikan penilaian validitas dengan kriteria yang dimodifikasi dari Purwanto $(2010: 82)$ berikut ini :

Sumber : Purwanto (2010 : 82)

\begin{tabular}{ccc}
\multicolumn{3}{c}{ Tabel 8. Klasifikasi Aspek Penilaian Validitas } \\
\hline No & Nilai Rerata & Aspek Yang Dinilai \\
\hline 1 & $90 \%-100 \%$ & Sangat Valid \\
2 & $80 \%-89 \%$ & Valid \\
3 & $65 \%-79 \%$ & Cukup Valid \\
4 & $55 \%-64 \%$ & Kurang Valid \\
5 & $\leq \quad 55 \%$ & Tidak Valid \\
\hline
\end{tabular}

2. Analisis Uji Praktikalitas Mobile Learning

Untuk mengetahui nilai Praktikalitas Mobile Learning berbasis android dilakukan langkah langkah seperti berikut:

a. Menentukan skor tertinggi Skor tertinggi $=$ jumlah validator $\mathrm{x}$ jumlah item pertanyaan $\mathrm{x}$ skor maksimum.

b. Menentukan jumlah skor dari masing-masing validator dengan menjumlahkan semua skor yang di peroleh dari masing-masing indikator.

c. Menentukan skor yang diperoleh dengan menjumlahkan skor dari masing-masing validator.

d. Penentuan nilai validitas dimodifikasi dari Purwanto (2010:102) sebagai berikut :

$N P=R / S M \times 100$.

Keterangan :

$\mathrm{NP}=$ Nilai persen yang dicari atau yang diharapkan

$\mathrm{R}=$ Skor mentah yang diperoleh Validator

SM = Skor Maksimum ideal dari tes yang bersangkutan

$100=$ Bilangan Tetap

e. Untuk mencari Distribusi Frekuensi dari Validitas dimodifikasi dari Agus Irianto sebagai berikut:

1)Menghitung jarak atau rentang $(R)$

$\mathrm{R}=$ data terting $\mathrm{i}-$ data terendah

2)Mencari jumlah Jumlah kelas (K)

$\mathrm{K}=1+3.3 \log \mathrm{n}$

3)Menghitung panjang kelas interval $(\mathrm{P})$ $\mathrm{P}=\mathrm{R} / \mathrm{K}$

Setelah presentase diperoleh, dilakukan pengelompokkan sesuai kriteria yang dimodifikasi dari Purwanto (2010 : 103) berikut ini :

Tabel 9. Penilaian Praktikalitas

\begin{tabular}{lll}
\hline No & Nilai & Aspek Yang Dinilai \\
\hline 1 & $86 \%-100 \%$ & Sangat Praktis \\
2 & $76 \%-85 \%$ & Praktis \\
3 & $60 \%-75 \%$ & Cukup Praktis \\
4 & $55 \%-59 \%$ & Kurang Praktis \\
5 & $\leq 54 \%$ & Tidak Praktis \\
\hline
\end{tabular}

Sumber : Purwanto (2010: 103) 


\section{Analisis Efektifitas Mobile Learning}

Untuk mengetahui nilai Efektifitas Mobile Learning dilakukan langkah-langkah seperti berikut:

a. Menentukan skor tertinggi, skor tertinggi $=$ jumlah siswa $\mathrm{x}$ jumlah item pertanyaan $\mathrm{x}$ skor maksimum.

b. Menentukan jumlah skor dari masing-masing siswa dengan menjumlahkan semua skor yang di peroleh dari masing-masing indikator dan menentukan skor yang diperoleh dengan menjumlahkan skor dari masing-masing siswa.

c. Menentukan skor yang diperoleh dengan menjumlahkan skor dari masing-masing siswa.

d. Data angket Efektifitas diperoleh dengan cara menghitung skor siswa yang menjawab masing-masing item sebagaimana terdapat pada angket. Data tersebut dianalisis dengan teknik persentase yang dinyatakan oleh Purwanto (2010 : 102) sebagai berikut :

$N P=R / S M \times 100$.

Keterangan :

$\mathrm{NP}=$ Nilai persen yang dicari atau yang diharapkan

$\mathrm{R}=$ Skor mentah yang diperoleh siswa

$\mathrm{SM}=$ Skor Maksimum ideal dari tes yang bersangkutan

$100=$ Bilangan Tetap

e. Untuk mencari Distribusi Frekuensi dari Efektifitas dimodifikasi dari Agus Irianto sebagai berikut :

1) Menghitung jarak atau rentang (R)

$\mathrm{R}=$ data tertinggi - data terendah

2) Mencari jumlah Jumlah kelas (K)

$\mathrm{K}=1+3.3 \log n$

3) Menghitung panjang kelas interval (P)

$\mathrm{P}=\mathrm{R} / \mathrm{K}$

Hasil yang diperoleh di interprestasikan dengan menggunakan kriteria sebagai berikut :

Tabel 10. Penilaian Efektivitas

\begin{tabular}{ccll} 
& \multicolumn{3}{c}{ Tabel 10. Penilaian Efektivitas } \\
\cline { 2 - 4 } No & Nilai & Aspek Yang Dinilai \\
\hline 1 & $86 \%-100 \%$ & Sangat Baik \\
2 & $76 \%-85 \%$ & Baik \\
3 & $60 \%-75 \%$ & Cukup \\
4 & $55 \%-59 \%$ & Kurang \\
& 5 & $\leq 54 \%$ & Kurang Sekali \\
Sumber : Purwanto (2010 : 103$)$ & &
\end{tabular}

\section{Hasil Dan Diskusi}

Proses pembuatan Media Pembelajaran Mobile Learning Berbasis Android dilakukan sesuai proses pengembangan yang peneliti terapkan, yaitu pengembangan berdasarkan model rancangan Modul Mobile Learning Perakitan PC, deskripsi data.

\subsection{Model Rancangan Mobile Learning}

a. Halaman Loading

Tampilan Halaman Loading merupakan halaman pembuka pada media pembelajaran Mobile Learning berbasis Android pada mata pelajaran Perakitan PC. Gambaran halaman loading ini sebagai berikut :

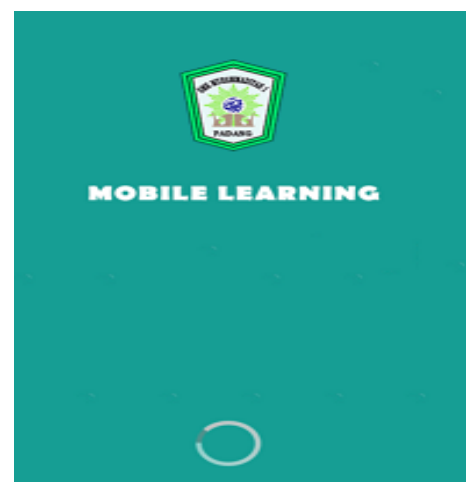

Gambar 3. Halaman Loading Mobile Learning 
b. Halaman Intro

Halaman Intro merupakan tampilan awal dari Media Mobile Learning berbasis Android setelah halaman loading. Halaman Intro ini memiliki satu tombol navigasi mulai yang berfungsi untuk masuk kehalaman utama/home.

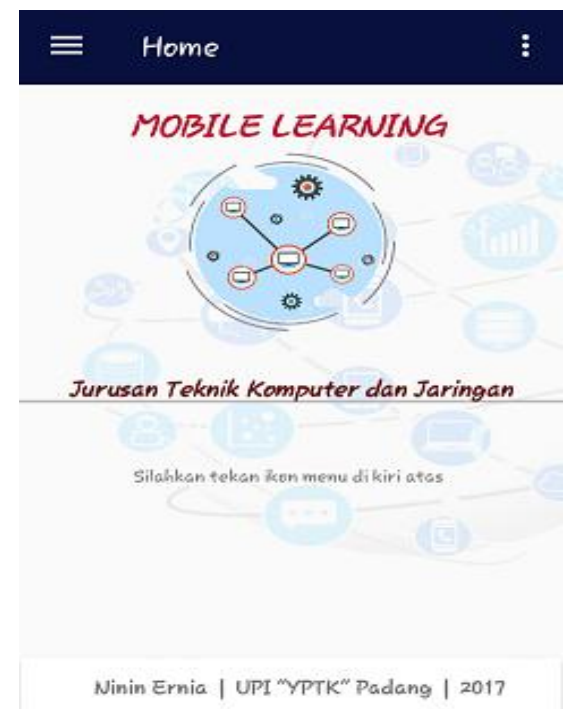

\section{Gambar 4. Halaman Intro Mobile Learning}

c. Halaman Menu Utama/home

Halaman Home merupakan halaman menu utama Mobile Learning , pada halaman ini terdapat enam tombol yaitu tombol home, user manual, meteri, evaluasi, about, dan video Gambar halaman menu utama dapat dilihat seperti dibawah ini:

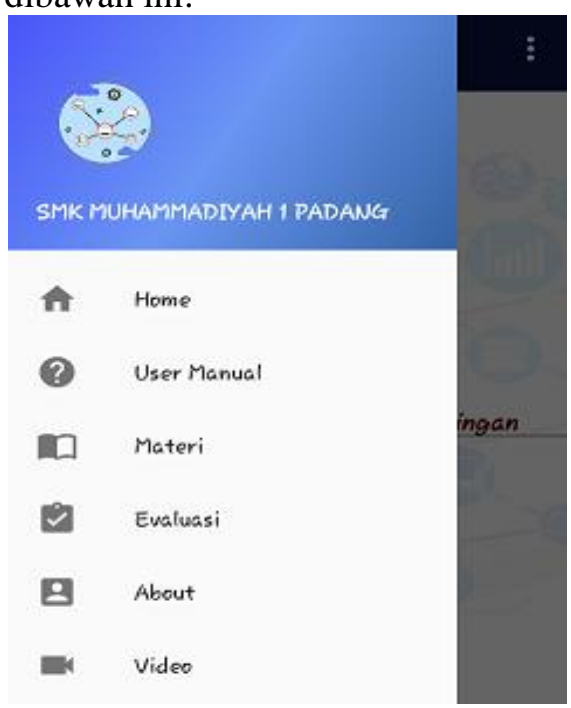

Gambar 5. Halaman Home

d. Halaman User Manual

Halaman user manual berisikan tentang petunjuk penggunaan setiap tombol yang ada pada media pembelajaran mobile learning dari Mata Pelajaran Perakitan PC. Gambar halaman user manual seperti dibawah ini : 


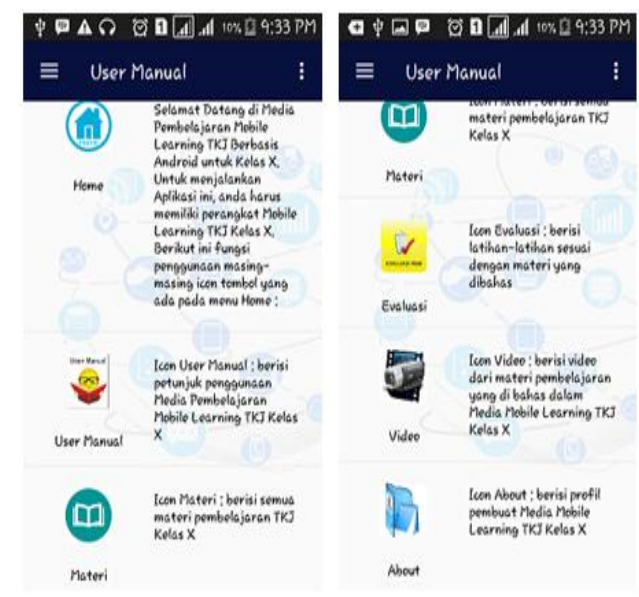

Gambar 6. Halaman User Manual

e. Halaman Materi

Halaman Materi ini berisikan tentang pilihan materi semester 1 dan 2 . seperti gambar dibawah ini :

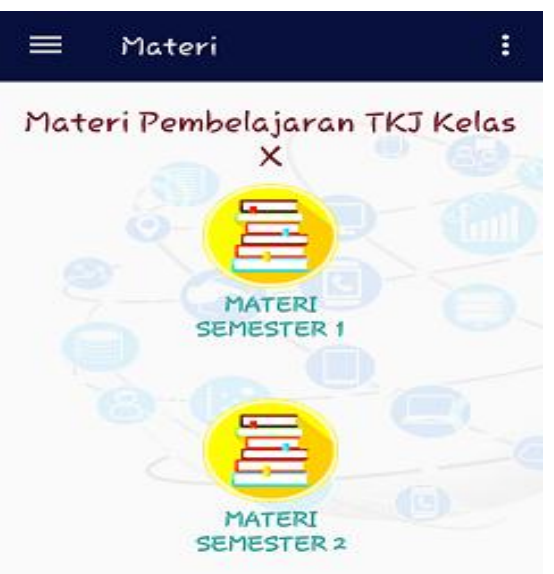

Gambar 7. Halaman pilihan Materi

f. Halaman Sub Materi

Sub Materi ini berisi pilihan materi semester 1 dan semester 2 dilengkapi SKKD dan Glosary. Seperti gambar dibawah berikut ini :

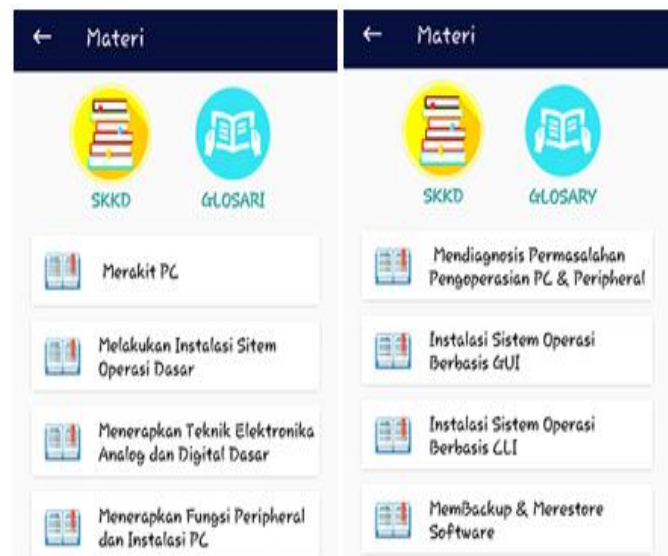

Gambar 8. Halaman Pilihan Materi Semester 1 dan 2

g. Halaman Menu Pilihan Latihan

Menu Pilihan Latihan berisikan tentang piliha soal-soal semester 1 dan 2 berhubungan dengan materi yang telah disampaikan. 


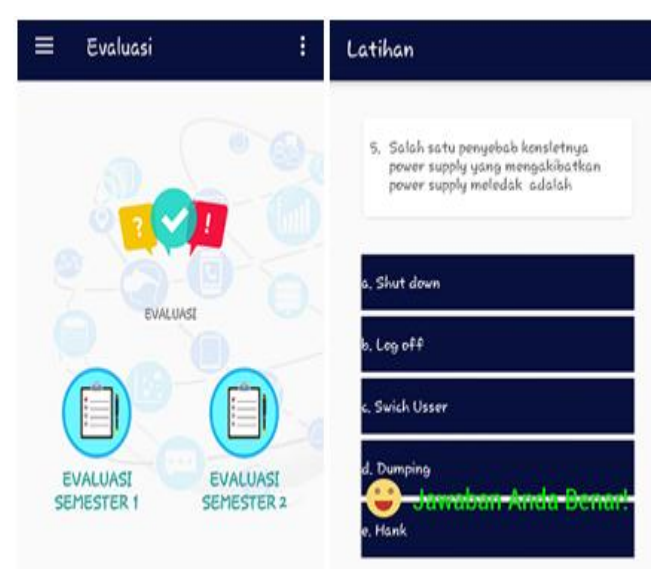

Gambar 9. Menu pilihan Latihan dan Jawaban Benar Evaluasi

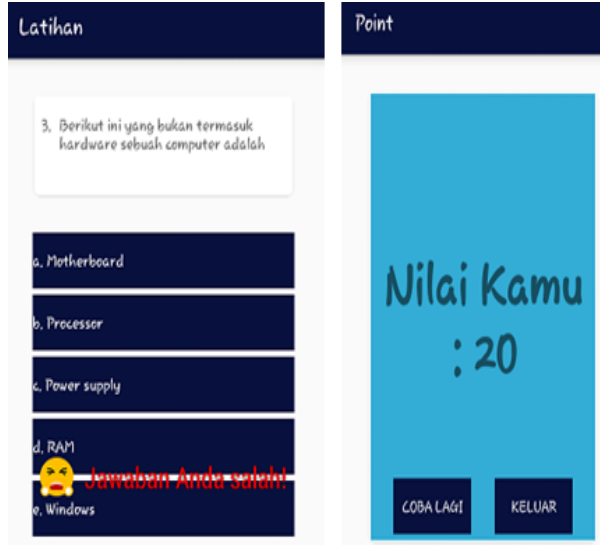

Gambar 10. Halaman Jawaban Salah dan Skor/Hasil Evaluasi

h. Halaman About/Profil

Tombol Profil ini menampilkan tentang biodata diri perancang dan pembuat media Mobile learning berbasis android. Gambar tampilan profil adalah sebagai berikut:

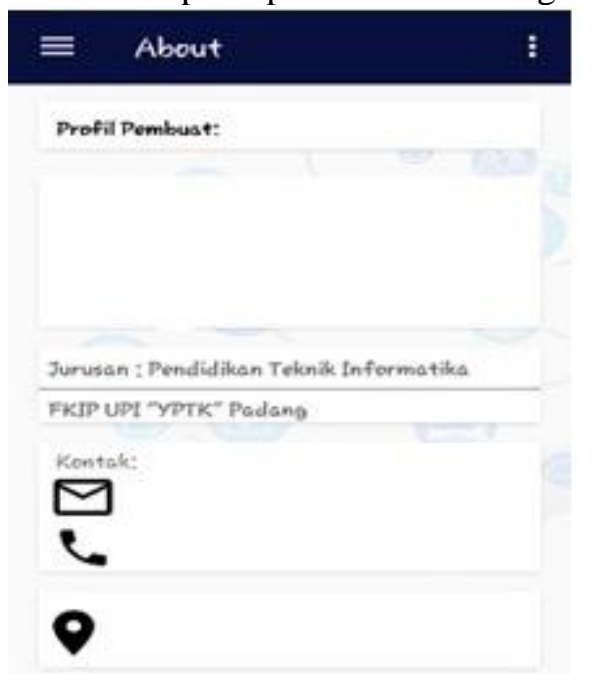

Gambar 11. Tampilan Profil

i. Halaman Video

Halaman video berisi pilihan navigasi video tentang materi semester 1 dan 2 : 


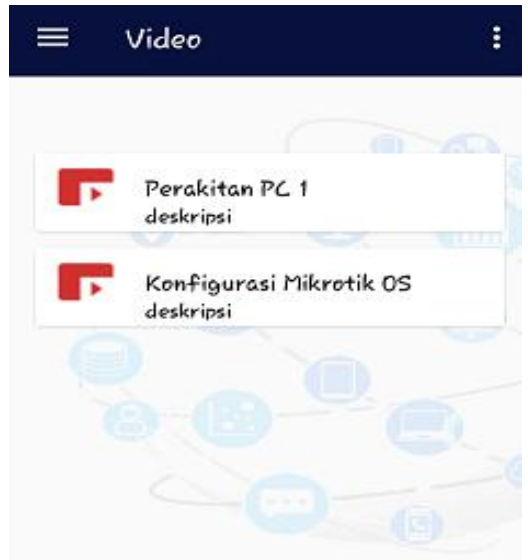

Gambar 12. Tampilan Video

\subsection{Hasil Uji Pengguna}

Uji pengguna diberikan kepada 3 kuesioner yang telah ditentukan dapat dilihat pada tabel berikut ini :

Tabel 11. Hasil Uji Pengguna

\begin{tabular}{|c|c|c|c|}
\hline No & Kuesioner & Nilai & Kriteria \\
\hline 1 & Validator & 88,58 & Valid \\
\hline 2 & Praktikalitas & 84,29 & Praktis \\
\hline 3 & Efektivitas & 87,51 & $\begin{array}{l}\text { Sangat } \\
\text { Efektif }\end{array}$ \\
\hline
\end{tabular}

\section{KESIMPULAN}

Pengembangan Mobile Learning berbasis Android mengikuti prosedur dan pengembangan (Research and Development) Sugiyono (2014:298). Berdasarkan diskripsi, analisis data, dan pengembangan Mobile Learning berbasis Android dapat disimpulkan sebagai berikut :

1. Kevalidan oleh penilaian uji validator terhadap Mobile Learning berbasis Android Perakitan PC sebesar $88.58 \%$, sehingga tingkat validitas dapat di interprestasikan Valid digunakan.

2. Kepraktisan terhadap Mobile Learning berbasis Android Perakitan PC sebesar $84.29 \%$, sehingga tingkat praktikalitasnya dapat di interprestasikan sangat praktis digunakan.

3. Keefektifan terhadap media pembelajaran Mobile Learning berbasis Android Perakitan PC 87,51\%, sehingga tingkat efektifitasasnya dapat di interprestasikan baik digunakan.

\section{DAFTAR PUSTAKA}

[1] Arsyad, Azhar. 2010. Media Pembelajaran. Jakarta. Rajawali Press

[2] Arsyad, Azhar. 2013. Media Pembelajaran.Jakarta.Rajawali Pers

[3] Sugiyono,2011. Metode Penelitian Kuantitatif, Kualitatif Dan R\&D. Bandung : Alfabeta

[4] Sugiyono,2012. Metode Penelitian Kuantitatif, Kualitatif Dan R\&D. Bandung : Alfabeta CV

[5] Rusman, 2012. Belajar dan Pembelajaran Berbasis Komputer. Bandung : Alfabeta.

[6] Gian Dwi Oktiana (2014). Skripsi dengan judul Pengembangan Media Pembelajaran Berbasis Android Dalam Bentuk Buku Saku Digital Untuk Mata Pelajaran Akuntansi Kompetensi Dasar Membuat Ikhtisar Siklus Akuntansi Perusahaan Jasa di Kelas XI MAN 1 Yogyakarta.

[7] Daflen Dian Erata (2015). Skripsi dengan judul Pengembangan Media Pembelajaran Berbasis Eclipse pada Android untuk Mata Pelajaran Produktif Instalasi Jaringan Komputer Untuk Kelas XI TKJ Semester Genap SMK Negeri 1 Sawahlunto.

[8] Indra Wijaya. 2010. Perancangan dan Pembuatan CD Multimedia Interktif Mata Pelajaran Kimia pada mata diklat konsep Materi dan Perubahannya untuk kelas X Sekolah Menengah Kejuruan (SMK) adzkia padang.

[9] Trianto.2007. Model Pembelajaran Terpadu Dalam Teori Dan praktek. Jakarta : Prestasi Pustaka

[10] Thiagarajan,dkk.1974. Instructional Development For Training Teachers of expectional Children. Minneapolis, Minnesota:LeadershipTrainingInstitute/Special Education, university of Minnesota.

[11] http://bustangbuhari. wordpress.com/ 2011/08/25/ four-d- model model pengembangan - perangkat pembelajaran -dari-thiagarajan-dkk.di akses04/11/2016

[12] Nazruddin Safaat.2013. Aplikasi Berbasis Android.berbagai implementasi dan pengembangan aplikasi Mobile berbasis Android.Bandung: Informatika Bandung. 